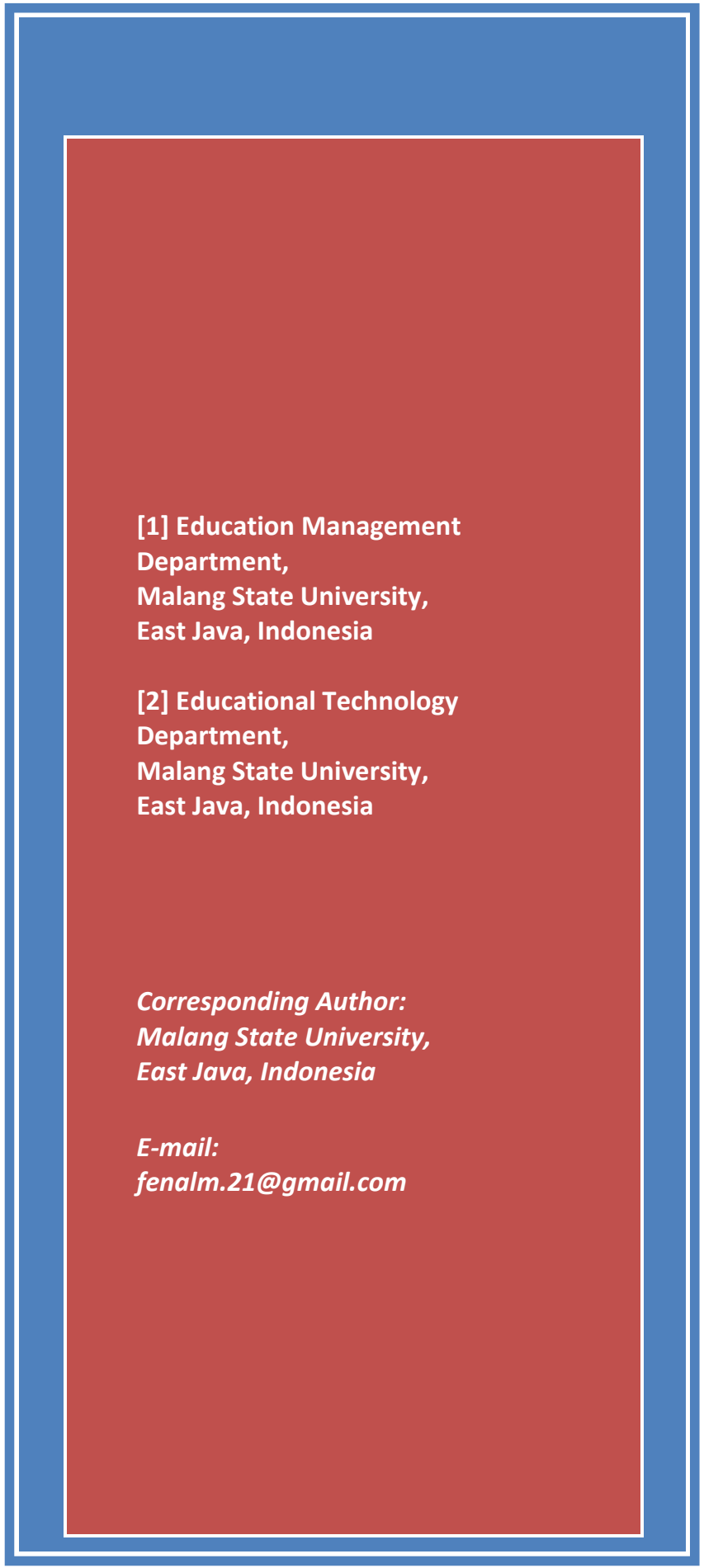

\section{THE PRINCIPAL'S TRANSFORMATIONAL LEADERSHIP APPROACH BASED ON LOCAL WISDOM IN STRENGTHENING THE CHARACTER OF STUDENTS}

Yulius Rustan Effendi ${ }^{1^{*}}$, Ibrahim Bafadal $(\mathrm{PhD})^{1}$, I Nyoman Sudana Degeng $(\mathrm{PhD})^{2}$, Imron Arifin $(\mathrm{PhD})^{1}$
[1] Education Management

Department

Malang State University,

Malang State University,

East Java, Indonesia

Corresponding Author:

Malang State University,

East Java, Indonesia

E-mail:

fenalm.21@gmail.com 


\section{MALAYSIAN ONLINE JOURNAL OF EDUCATIONAL MANAGEMENT (MOJEM)}

\section{INTRODUCTION}

Progress in the era of industrial revolution 4.0 causes a positive change and progress in various aspects of life, including education aspects. Another fact illustrates that development and change have led to ambiguous behavior in Indonesian students, especially on the students in Manggarai, West Flores, Indonesia. Life behavior that wants freedom causes students to be involved in promiscuity, free sex, drug use, and alcohol consumption. Group competition in a multicultural environment causes students to fall into intolerant life attitudes. Group competition among students with unstable emotional conditions causes brawls between students. Regulations established in schools are often not adhered to because they want to live freely. Besides, their dressing and speech style tend to imitate the actors and actresses in the soap opera. As a result, the students dressed unethically in public and speak unethical while in school and at home.

In responding to moral deviations, the Indonesian Ministry of National Education has established a CESP to continue the implementation of character education that has been running since 2010. The Indonesian government has revitalized the national education policy through the Government Regulation of the Republic of Indonesia number 87 of 2017, on character education strengthening [CES], Chapter I, article 1 which emphasized, that CESP is pedagogical activities that unite the heart, taste, mind, and body. Government regulations are essential to be implemented in schools, as an anticipatory and curative step in overcoming moral deterioration that occurs among students. This regulation is achieved through intensive coordination with teachers, employees, students, parents, school committees, the community, including the critical role of the principal.

Even though the Indonesian government has revitalized national education policies, the CESP has not been implemented optimally in schools. The cause of this failure is the school principals' policy and approach patterns that do not support the values of CES. Firstly, the principal's policy of establishing national character values (NCV) as the central character values in schools is considered impractical and not contextual. It is because NCV is conceptual, do not have LCMV, and have an effective political content (Wibowo, 2015). Indonesian people share different ethnic and cultural norms (Kleden, 1987). Therefore, the standards of character values set in schools must follow the values and rules of local culture that have been integrated with students' life behaviors. If NCV is still applied, local students will be alienated from their environment and experience an identity crisis. Their life behavior will not follow the demands of moral values and culture that they have.

Secondly, the pattern of the approach used by school principals is not relevant to local culture (Ardiawan, 2018). It is because a leader needs to adjust his approach pattern to culture in the work environment, and cultural characteristics that blend with patterns of follower behavior (Bass, 1997; Hartog, Hangees, Dorfman, \& RuizQuintanilla, 1999). According to Leithwood and Jantzi (1999), this condition shape contextual work performance that is appropriate to the culture and climate of an organization. This statement is based by the research findings of Tapung, Maryani, Lon, Payong, and Supriatna (2018), who examined the impact of planting the value of lonto leok in the study of social sciences in junior high and high school students in Manggarai Regency, West Flores, Indonesia. The cultivation of lonto leok values in learning shapes students' social character successfully, thereby overcoming students' social problems. Sutam (2014) examines the impact of applying the lonto leok culture by a leader in Manggarai. He finds positive acceptance of the role of a leader by the Manggarai community using the lonto leok culture teaching dimension approach [LLCTDA]. Besides, Irawanto, Ramsey, and Ryan (2011) discover changes in subordinates' performance when leaders used the paternalistic leadership patterns of Javanese culture in the Provincial Government of the Yogyakarta Capital Region. Additionally, Yunus (2014) examines the impact of the transformation of 'Huyula' cultural values in building the nation's character in the city of Gorontalo, South Sulawesi Province. Research by Surya, Thoyib, Fatchan, and Rahayu (2014) also reveals a positive influence on the culture of 'Tri Hita Karana' applied by leaders to advance the company's performance. When reviewing previous research with the research we conducted, we found significant differences. Previous research was limited to cultural approaches in learning by teachers, local leaders in running the local government, and company leaders in advancing companies. At the same time, this study describes a cultural approach in the form of the use of the 


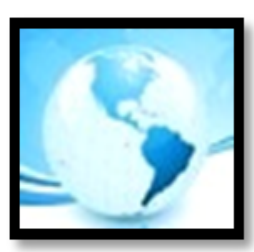

\section{MALAYSIAN ONLINE JOURNAL OF EDUCATIONAL MANAGEMENT (MOJEM)}

lonto leok cultural moral values [LLCMV], from the Manggarai community, West Flores, Indonesia, as a standard of character values in schools. This study also describes the steps in applying the lonto leok culture approach by the school principal to optimize the implementation of a CESP at one of the junior high schools in West Flores, Indonesia.

The principals use LLCMV as a standard for character values in school because the LLCMV has become the norm and the values that underpin the life order of teachers, employees, students, parents, and the community (Tapung et al., 2018). Besides, it is motivated by the environmental conditions of schools and communities who hold fast to cultural values and norms, coupled with an adequate headmaster's knowledge of the culture of lonto leok, encouraging school principals to adopt the LLCTDA in carrying out their roles. Furthermore, the principal also unites the cultural approach with the transformational leadership model conceptualized by Podsakoff, MacKenzie, Moorman, and Fetter (1990), and Leithwood and Jantzi (1999). The dimensions of transformational leadership combined teaching lonto leok culture are; articulate the vision, provide intellectual stimulation, offer individual support, describe professional practices and values, show high-performance expectations, and develop structures to encourage participation in school decisions. Meanwhile, the effectiveness of the LLCTDA was assessed by comparing it with the national cultural dimension of Hofstede (1984), which includes; power distance, avoidance of uncertainty, individuality, and masculinity.

\section{Research Objectives or Questions}

This research broadly explores the moral values of the lonto leok culture of the Manggarai community, Eastern Indonesia, as a standard for character values in schools. In addition, this study describes the role of transformational leadership principals lonto leok based approach to culture in optimizing the implementation of the program of strengthening character education in schools. The main question of this research is how the moral values of Lonto Leok culture and the principal's leadership approach contribute to strengthening the character of students at school? The purpose of this study is to describe the application of the moral values of Lonto Leok culture, and the principal's approach in optimizing the program of strengthening character education in schools. To overcome common challenges related to the implementation of character education strengthening programs, this study aims to answer the following research questions:

1. How to apply the moral values of Lonto Leok culture in school?

2. How to optimize the contribution of the principal in the role of strengthening educational programs in schools?

\section{Education, Culture, and Character}

The basic concept of the educational purpose is to guide students to gain the science and discipline of personal character (Obanya, 2005). Culture is a habit pattern in building relationships with other humans and nature. This habit pattern is formed through a system of thinking following the values and norms of a shared life (House et al., 1999). Character is the personal wealth that is owned by someone to set how to behave in their personal lives and in the lives of others (CEP, 2002). CES is the act of directing one's life in harmony with the heart, feelings, thoughts. This action is pedagogically meaningful and conducted together by schools, parents, and communities in educational activities (Ministry of Education [MoE], 2017). Thus, character education is a continual education program to establish and develop someone's character. This character development aims to prepare students to face the current and future demands of life (UNESCO, 2012).

In the era of the Industrial Revolution 4.0, students are not only required to have a strong character, but also to be genuine, positive, and constructive. Therefore, developing these characters requires pedagogic strategies. One of those strategies is conditioning a school environment that is orderly, disciplined, respectful, friendly, speak, and dress politely, as well as tolerant in responding to differences. This condition is derived from habituation and imitation of the teacher's behavior by students. The second strategy is to conditioning the classroom environment 


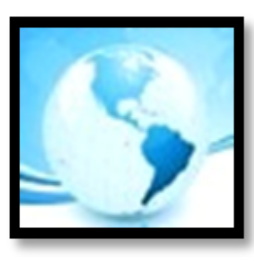

\section{MALAYSIAN ONLINE JOURNAL OF EDUCATIONAL MANAGEMENT (MOJEM)}

through learning strategies that foster student character. The strategies involve child-friendly, fun, appreciate honesty, fair treatment, free to convey thoughts, respect the opinions of others, guide students with love, solve students' problems with empathy, understanding, and tenderness, free of bullying. The third strategy is to condition the family and community environment by giving an exemplary behavior following local values and cultural norms.

For the school environment, classrooms, and society should be optimally conditioned to develop a culture of inclusion and evolution (Nieto, 2008). Development of inclusive culture is an effort to create the school environment that is open, friendly, democratic, safe, comfortable, fair, and include all people with different backgrounds, characteristics, abilities, status, conditions, ethnicity, culture (Koesoema, 2017; MoE, 2017).

Thus, the character formation of students occurs in social life with the values and norms of a particular culture. Education that promotes cultural values strongly supports students to appreciate their identity, respect codes of living together, and appreciate the moral values (Ladson-Billings, 1992).

\section{Moral Values of Lonto Leok Cultural Education}

Lonto leok is one of the local wisdom owned by the people of Manggarai, West Flores, Indonesia. The word lonto leok consists of two syllables, and each word has a meaning. The word lonto means to sit, and the phrase leok represents to be circular. Thus, the term lonto leok means the model sits together in a circle. Sitting position like this is done at joint meetings and traditional parties. (Verheijen, 1967). Lonto leok culture originates from the symbol of a conventional house (Mbaru: House; Gendang: together) in the form of a circle and a form of division of agricultural land called lodok that forms a spider's web. These two symbols are the main reasons why Manggarai people practice lonto leok culture (Sutam, 2014). The core meaning of lonto leok culture explains the philosophy of life containing moral values that shape the character of the Manggarai community and the school community in particular.

Lonto leok is a philosophy of life that contains moral values and dimensions of teaching that influence others. The moral values in lonto leok are; (1) democracy, in the form of participation to give and receive every thought, as well as openness to accept the decision together; (2) unity, to unite differences and strengthen the relationship of lineages from one generation to the next; (3) peace, respecting others, and avoiding conflict; (4) love, which is based on Christian love; (5) justice, especially in the fair distribution of agricultural land (lingko); (6) honesty, which emphasizes the similarity between words and deeds; (7) hard work, to fulfil a decent life, and be able to finance children's education; and (8) friendliness, in communicating with others, without creating differences (Tapung et al., 2018).

Other researchers have investigated the meaning of the LLCMV. Erb (2005) examines the role of the political elite in reforming the image of local culture, including one of the lonto leok cultures in building a 'New Manggarai' to support decentralization and democratization policies in the post-1998 reform era. Sutam (2014) also investigates the impact of the lonto leok culture approach in Manggarai marriage traditional ceremonies. Additionally, Nggoro (2013) analyses the effectiveness of group learning for elementary students based on the lonto leok culture. The focus of previous research on the inculcation of democratic values in learning and the use of democratic aspects by community leaders. On the other hand, our research focuses on the principal's policy of exploring, discovering, and developing seven elements of the LLCMV. Those aspects are then jointly determined (teachers, employees, parents, school committees, community leaders, traditional leaders, and school supervisors) as standard values of the primary school characters and school branding.

\section{Principal Transformational Leadership Approach Based on Lonto Leok Cultural Values}

Principal leadership behavior implies changes and school progress, in the form of teacher work quality, the effectiveness of school programs, and student achievement (Leithwood \& Jantzi, 1999). The effectiveness of 


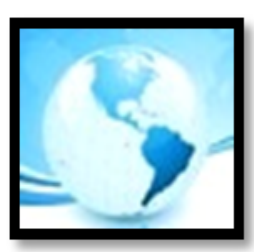

\section{MALAYSIAN ONLINE JOURNAL OF EDUCATIONAL MANAGEMENT (MOJEM)}

principals' leadership is related to local cultural conditions (Spreitzer, Hopkins, \& Xin, 2005). Different cultural characteristics in human life require different transformational leadership approach. The culture emphasizes the sense of identity and "ownership" of certain groups, through norms, rituals, values, beliefs, and language to do something. Different cultural characters in society require adaptive TLB. Thus, culture can influence the concepts, styles, and practices of transformational leadership. (Hofstede, 2001).

In optimizing the implementation of CES, the principals used TLB approach developed by Podsakoff et al. (1990), and Leithwood and Jantzi (2006), and explained by other experts, and being supported through the LLCTDA, the Manggarai community. First, the school principal encourages the progress of the school, based on the vision, mission, and shared goals, through the LLCTDA in the form of "tatong" (encouraging growth and change) (Sutam, 2014). The LLCTDA opposes traditional leader behavior, which maintains the status quo (Hofstede, 1993). Second, intellectual stimulation, supported by the LLCTDA in the form of "toing" (teaching how to overcome problems). The principals give opportunities to subordinates to develop creativity and innovation to overcome old challenges in new ways (Sutam, 2014). Third, offers individual support, and is supported by the LLCTDA, in the form of "toto nai bakok" (showing an expression of partiality). The behavior of this leader, by the LLCTDA, is in the form of "toto nai bakok" (indicating an illustration of partiality). The presence of leaders fosters self-confidence, attention, the trustworthiness of subordinates, and attention to the needs of subordinates (personal and their families).

Fourth, professional practice and values are supported through the LLCTDA of "titong" (provides guidance to do something responsibly). The presence of leaders becomes a guide and role model for subordinates. This dimension rejects the behavior of traditional leaders who are authoritarian and keeps the distance between leaders and subordinates (Sutam, 2014). Fifth, high-performance expectations. The supporting LLCTDA are "tatang or titing" (strengthening and empowering). Leaders provide inspirational motivation to encourage subordinates to do more than they should target (Sutam, 2014; Yammarino, Dubinsky, \& Spangler, 1998). This dimension opposes the culture of conformity, nepotism, and loyalty. Sixth, the development of structures for participation. The LLCTDA under this leadership behavior is "bantang cama reje leleng" (cooperation). The presence of leaders revives togetherness and participation to achieve common goals (Leithwood \& Jantzi, 1999). The LLCTDA emphasizes gender alignments and opposes individualism and masculine dominance in traditional culture (Hofstede, 1993).

\section{METHODS}

This research used a qualitative approach with a case study designed to obtain written and oral data arranged in sentences based on the interview with the participant (Miles, Huberman, \& Saldaña, 2014). The qualitative research method is established by the post-positivism paradigm to investigate natural phenomena or objects. In regard to this method, the researchers wished to observe and describe the reasons that schools combine primary national character values and moral values of lonto leok local culture from Manggarai society.

The researchers also wanted to discover and interpret the practice of principal transformational leadership based on teaching dimensions of lonto leok local culture from Manggarai society. This research was carried out in two locations, State Junior High School 1, Private Catholic Junior High School, and Private Islamic Junior High School. These three schools are located in Manggarai, West Flores, East Indonesia. These schools were selected due to their environments are greatly influenced by lonto leok local cultural values.

The data source was based on people and schools. The data was obtained through a structured interview with the school's principal, teachers, students, parents, school committee, and local cultural figures. The participants were chosen to attain information related to the main reasons that schools included the local cultural moral values of Lonto Leok as the school branding. Additionally, to obtain information about the practice of school principal transformational leadership based on the teaching dimension of lonto leok. These two research focuses were investigated and described to prove that the schools have implemented character education reinforcement 


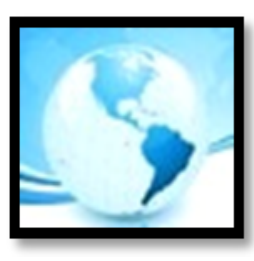

\section{MALAYSIAN ONLINE JOURNAL OF EDUCATIONAL MANAGEMENT (MOJEM)}

optimally. The interview is used to reveal the participants' point of view in interpreting people, phenomena, organizational activities, feeling, motivation, and acknowledgment toward the research focus (Miles et al., 2014).

On the other hand, the observation was completed to profoundly recognize the measure of a specific group, the behavioural values of each individual, beliefs, and each participant's ways to accomplish the task in school. The observation was focused on the researchers' participation with the people involved in it (Creswell, 2012). The observation is exceptionally essential to complete and test the data validity by comparing the incomplete interview results with the observation results. Thus, the obtained data became more comprehensive. On the other hand, the observation was completed to profoundly recognize the measure of a specific group, the behavioural values of each individual, beliefs, and each participant's ways to accomplish the task in school. The observation was focused on the researchers' participation with the people involved in it (Creswell, 2012). The observation is exceptionally essential to complete and test the data validity by comparing the incomplete interview results with the observation results. Thus, the obtained data became more comprehensive. The measurement of the validity of the data used a triangulation process. The data triangulation process took several stages, namely: (1) comparing observation data with interview data; (2) comparing what participants say in public with the reality on the ground; (3) comparing one's circumstances and perspectives with other's views; (4) comparing the results of interviews with the contents of related documents. (5) comparing facts with one or more theories as a comparative explanation; (6) a peer examination was performed through discussion with a peer; (7) negative case analysis, by collecting examples of cases that were not based on patterns and trends of information that had been collected and used as a comparison; (8) examining members, checking whether the data recorded and interpreted by the researchers was appropriate and key informants recognized the truth.

Besides, the data analysis was completed through a process of systematically finding and organizing the interview transcript and field notes. Then, the data were sorted and grouped to establish the research focus and theory (Creswell, 2012; Miles et al., 2014). In data analysis, the researcher described the situation or the phenomena that form the character in detail. Each person's experience on the involvement in character reinforcement activities, their behavior in supporting the activities, their trust in the activities, and their opinions that illustrate the whole activities of character reinforcement in schools. Besides, the researchers also observed the interactions and behavior that indicate excellent characters have been formulated in schools (Miles et al., 2014; Yin, 2017).

\section{RESULTS}

The data collected from key participants show points related to the principal's policy in the process of determining the standard values of the main characters in schools extracted from the LLCMV. Furthermore, the steps of the transformational leadership role of the school principal are supported by the LLCTDA, starting from the planning, implementation, and evaluation of CESP.

\section{Lonto Leok's Moral Cultural Values That Support the Role of a Leader}

The data collected from two traditional elders, as key participants, reveals that lonto leok is one of the cultural heritages that contains the community's moral values and norms for life and guidance for a leader in applying the LLCTDA. In tracing the history of the Manggarai people in the past, traditional leaders named "Tua Golo" (Tua: elders; Golo: Region), and King (Manggarai: Dalu) as community leaders, had placed LLCTDA relationship with transformational practices leadership. Integrating transformational leadership models and cultural dimensions are typical of the Manggarai leadership model. Two traditional leaders explained as follows.

The Lonto Leok teaching values approach strongly supports the role of a leader in several aspects. a) "tatong" (encouraging development and change), b) "toing" (teaching life), c) "titong" (giving guidance in running life), d) "tatang or titing" (empowering the potential of others), e) "Toto nai bakok" (a heart that cares), f) "bantam cama reje leleng" (cooperation). (Interview, November 20, 2018) 


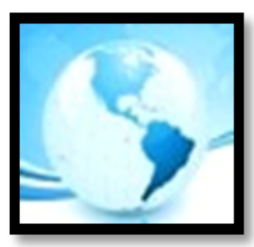

Furthermore, related to the source of inspiration formed Lonto Leok culture, explained by the two traditional leaders as follows.

Lonto Leok culture is inspired by the symbol of traditional houses (mbaru gendang) and agricultural land (lodok) (Interview, November 20, 2018)

The cultural symbol of lonto leok is illustrated in Figure 1.

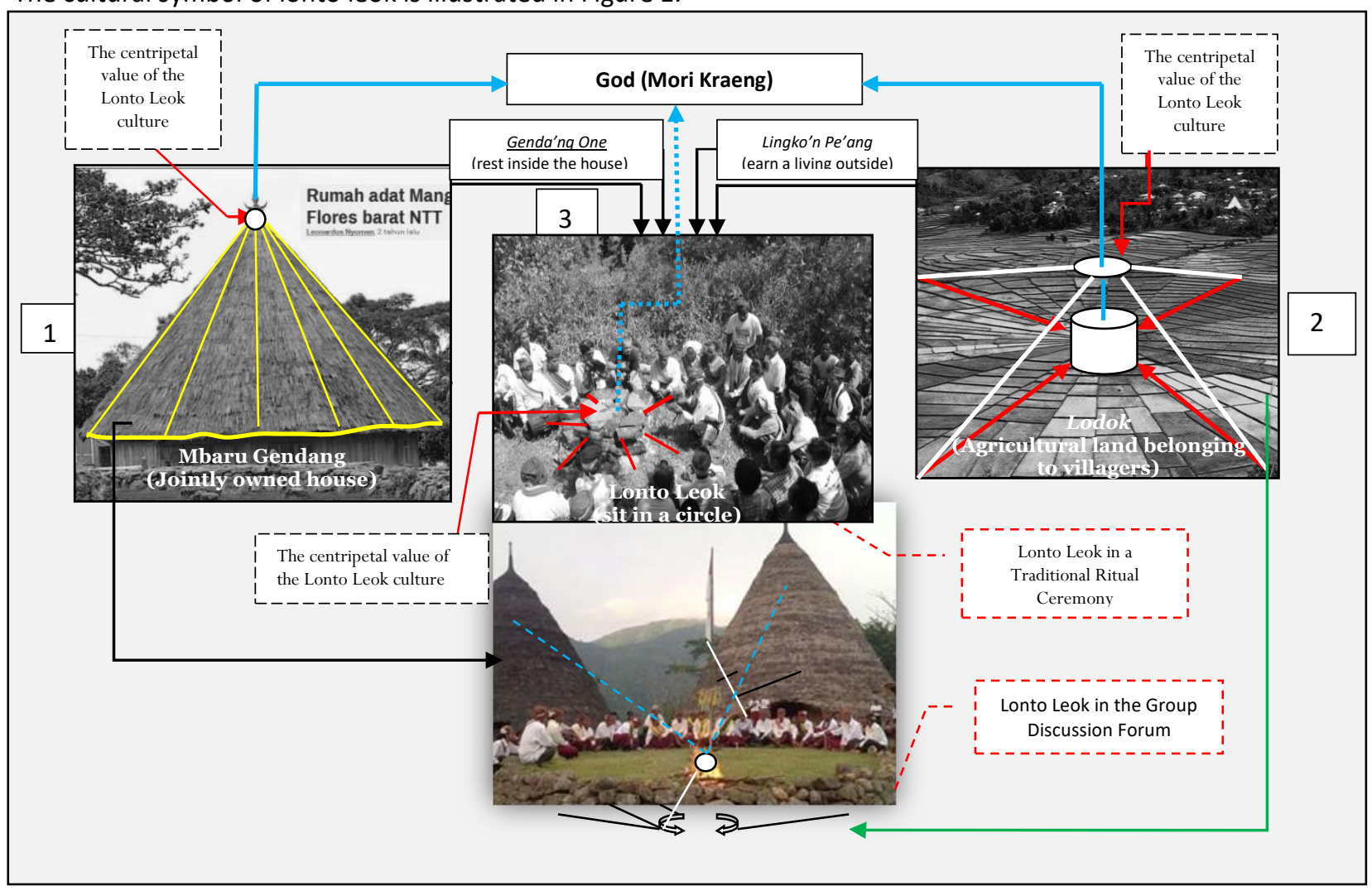

Figure 1. Cultural symbol of "Lonto Leok" (Mbaru Gendang and Lingko/Lodok)

Photo Source. : West Manggarai District Tourism Office

According to figure 1, number 1 represents one of the life philosophies of the Manggarai people, symbolized by a traditional house (mbaru gedang) in the form of a circle that leads to the top forming a cone. This symbol describes that all plans of human activity are taught together at home, and the goal is that each activity brings the safety of the Highest (Mori Kraeng). Meanwhile, number 2 depicts one philosophy of life, which is agricultural land (lodok) in the form of cobwebs. That symbolizes all human activities on earth that always move towards the centre of life (centripetal), which is the Highest (Mori Kraeng). Number 3, on the other hand, represents that all human activities need to be regulated, directed, and guided by a leader. The presence of a leader is believed to be a manifestation of the existence of the Supreme Being (Mori Kraeng) that guides fellow human beings to live in the regularity of values and norms to create a harmonious life and gain salvation after death.

The cultural symbol of lonto leok inspires the harmony of the Manggarai community life and spiritual appreciation for salvation after death. The manifestation of life harmony is shown through moral actions, such as; (a) democracy, prioritizing the right to speak and accept joint decisions; (b) unity, solving problems without conflict; 


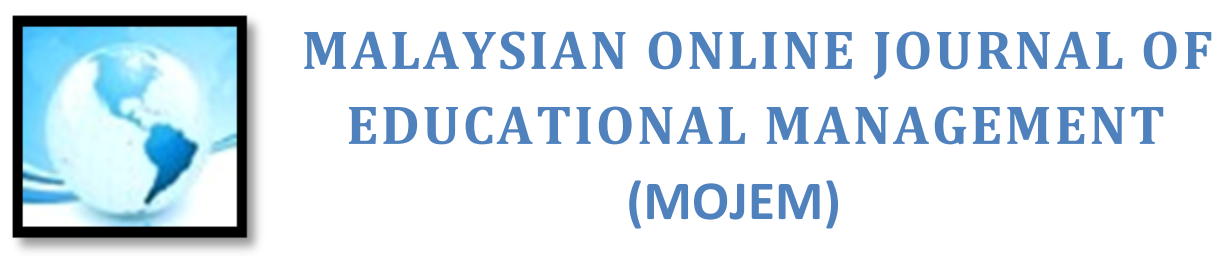

(c) peace, prioritizing life safe, peaceful and peaceful; (d) love, which is inspired by the values of Christian love; (e) fair, in the distribution of agricultural land, and other interests; (f) honest, in words and deeds; (g) hard work, for the welfare of life; (h) friendliness, accepting others without distinction. In education, moral values lonto leok are the standard for student character values. These character values become the school's branding and are strengthened by the words of idiomatic called "go' et" as the driving and unifying mind, heart, and action. The following is a comparison table of the values of the main characters of Indonesian national character education and the values of lonto leok character, from the Manggarai community.

Table 1

Values of National Main Characters and Character Values of Lonto Leok

\begin{tabular}{|c|c|}
\hline Values of the National Main Character & Lonto Leok's Character Values \\
\hline $\begin{array}{l}\text { Religious } \\
\text { Sub-Value: peace of mind, tolerance, firm stance, } \\
\text { self-confidence, cooperation, rejecting } \\
\text { immoral behavior and violence, friendship, } \\
\text { sincerity, not imposing the will, loving the } \\
\text { environment, protecting the small and } \\
\text { marginalized }\end{array}$ & $\begin{array}{l}\text { - Democracy } \\
\text { Sub-Value; respect others, be humble, and respect } \\
\text { differences. Go' et (idioms): } \\
\text {-. bantang cama reje leleng } \\
\text { - Unity } \\
\text { Sub-Value: family, solidarity, and integrity. Go' et (idioms): } \\
\text {-. ca natas bate labar, ca uma bate duat; ca wae teku, agu }\end{array}$ \\
\hline $\begin{array}{l}\text { Nationalist } \\
\text { Sub-Value: the appreciation of the nation's } \\
\text { culture, willing to sacrifice, excel, and excel, } \\
\text { love the country, protect the environment, } \\
\text { obey the law, discipline, respect the diversity } \\
\text { of cultures, ethnicities, and religions }\end{array}$ & $\begin{array}{l}\text { ca mbaru bate Kaeng } \\
\text { - Peace } \\
\text { Sub-Value: friendship, and mutual love. Go' et (idioms): } \\
\text {-. ema agu anak neka woleng bantang } \\
\text {-. ase agu kae neka woleng tae } \\
\text { - Love }\end{array}$ \\
\hline $\begin{array}{l}\text { Independent } \\
\text { sub-value: work ethic (hard work), strong } \\
\text { hardiness, fighting the power, professional, } \\
\text { creative, courage, and a lifelong learner. }\end{array}$ & $\begin{array}{l}\text { Sub-value: religious attitude, solidarity, culture, and } \\
\text { ecological spirit. Go' et (idioms): } \\
\text {-. mohas agu momang hae ata } \\
\text { - Justice }\end{array}$ \\
\hline $\begin{array}{l}\text { Cooperation } \\
\text { Sub-value: cooperation, inclusiveness, } \\
\text { commitment to joint decisions, consensus } \\
\text { building, help, solidarity, empathy, anti- } \\
\text { discrimination, anti-violence, and voluntary } \\
\text { attitude. }\end{array}$ & $\begin{array}{l}\text { Sub-Value; fair treatment, respect for the rights of others. } \\
\text { Go' et (idioms): } \\
\text {-. eme de ata de ata muing, neka daku ngong data } \\
\text { - Honesty } \\
\text { Sub-Value; honest, don't lie. Go' et (idioms): } \\
\text {-. eng eme eng, toe eme toe } \\
\text { - Hard work } \\
\text { Hard Work Sub-Value: sacrificial attitude, discipline, } \\
\text { fighting spirit, and responsibility of Go' et (idioms): } \\
\text {-. dempul wuku tela toni - dari walis, runcung dureng } \\
\text { - Friendliness } \\
\text { Sub-Value: accept other people without any difference. Go' } \\
\text { et (idioms): } \\
\text {-. reis/ris, ruis, raes, raos }\end{array}$ \\
\hline
\end{tabular}

\section{Lonto Leok's Culture-Based Principal Transformational Leadership Approach}

\section{a. Planning phase}

The presence of a leader supports the Manggarai people in order to uphold the values of a harmonious, peaceful, and spiritual life. Ever since the royal times, a King (Dalu) has placed the teaching of lonto leok as a guideline. The dimension of The lonto Leok's teaching guides the mind, heart, and actions of the community. The same step is 


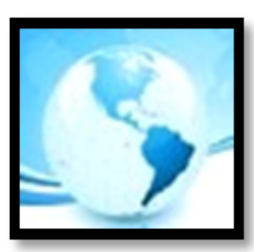

\section{MALAYSIAN ONLINE JOURNAL OF EDUCATIONAL MANAGEMENT (MOJEM)}

also practiced by the traditional/cultural leader called Tua Golo/Tua Gendang (Indigenous Elders), in directing the head of the clan (tua panga) and other members of the tribe, using dimensions lonto leok teaching as a doctrine that brings together all members of the tribe. Currently, the teaching dimension of lonto leok is also applied by the leaders in various social institutions, including the education sector. The aspects of teaching lonto leok are transformative dimensions of leadership values because they are not time-limited, practiced in various spheres of life, and following the background of the ethnicity, religion, race, class, and culture of the people who use them.

Recently, it was practiced in several schools in Manggarai-Flores, including three Junior High Schools in Manggarai Regency, West Flores - Eastern Indonesia. In the CESP, the steps of the lonto leok activity by the principal are discussed as follows.

First, establish networks of collaboration between schools, government, parents, school committees, and traditional leaders. In the lonto leok meeting, I allowed two traditional leaders to present the material on the lonto leok value. In the next discussion, participants determined the lonto leok character values that suitable for character values in the school. Second, I formed a special team comprising; three senior teachers representing the school, one traditional leader, one person from the government (education department of youth and sports), and two people representing parents. The team is responsible for formulating the vision, mission, and objectives of character education. (Interview, March 12, 14, 18, 2019)

Then the principal assigned each team member to design a lonto leok-based CEPS that includes; (1) selfdevelopment activities; (2) class activities; (3) school environment; and (4) society. Table 2 illustrates a comparison of the planning activities by general principals in Indonesia and the planning steps of the principal based on the lonto leok culture.

Table 2

Steps of General Indonesian Principals and the Steps of the Lonto Leok-Based School Principal at the Junior High Schools, Manggarai Regency, West Flores - Eastern Indonesia

\begin{tabular}{|c|c|c|}
\hline \multicolumn{3}{|c|}{ The Principals Planning Phase Steps } \\
\hline Steps of the principals & $\begin{array}{l}\text { Steps of principals in general in } \\
\text { Indonesia }\end{array}$ & $\begin{array}{l}\text { The steps of the principals based on the } \\
\text { values of lonto leok }\end{array}$ \\
\hline $\begin{array}{l}\text { Involving all school } \\
\text { components to } \\
\text { establishes the central } \\
\text { character values by the } \\
\text { school's vision, mission, } \\
\text { and goals }\end{array}$ & $\begin{array}{l}\text { - Not yet determined the standard } \\
\text { character values that are typical } \\
\text { for schools } \\
\text { - Does not involve parents, the } \\
\text { community, and stakeholders }\end{array}$ & $\begin{array}{l}\text { - Set the standard character values based on } \\
\text { the lonto leok values } \\
\text { - Involve various parties (principals, teachers, } \\
\text { employees, parents, government, } \\
\text { traditional elders / cultural thinkers, and the } \\
\text { community) }\end{array}$ \\
\hline $\begin{array}{l}\text { Formulation of the } \\
\text { school vision, mission, } \\
\text { and goals }\end{array}$ & $\begin{array}{l}\text { The formulation of the school's } \\
\text { vision, mission, and objectives is not } \\
\text { contextual and has no character }\end{array}$ & $\begin{array}{l}\text { Formulate the school's vision, mission, and } \\
\text { objectives that are contextual and } \\
\text { characterized }\end{array}$ \\
\hline $\begin{array}{l}\text { Character strengthening } \\
\text { program }\end{array}$ & $\begin{array}{l}\text { Combined with school activities. It is } \\
\text { challenging to distinguish the school } \\
\text { activities and character } \\
\text { strengthening } \\
\text { activities }\end{array}$ & $\begin{array}{l}\text { Compile special programs for character } \\
\text { strengthening activities }\end{array}$ \\
\hline
\end{tabular}

\section{b. Implementation phase}

The Lonto Leok program was implemented for one semester (6 months) in the school. That one semester was divided into two stages. Each step takes three months. After the first step was completed, a midterm evaluation was conducted. The results of the midterm evaluation were used to improve the implementation of the program in 


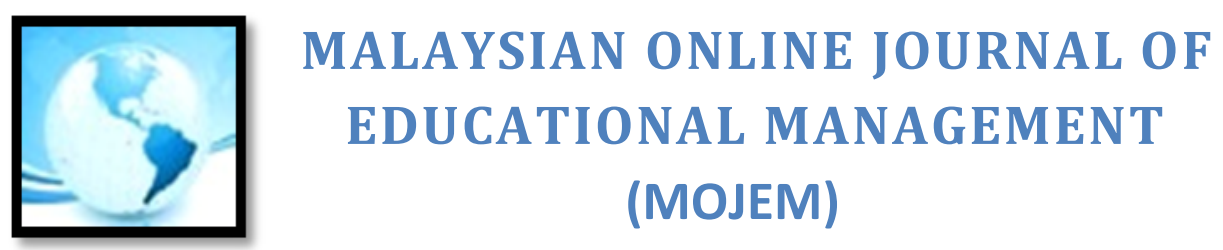

the second stage. At the end of the semester, another assessment was conducted. Regarding the implementation phase, explained by the principals as follows.

In the implementation of the lonto leok program, I always directed the teachers and staff by providing aspects of teaching lonto leok culture that contains moral values. This was done in a morning meeting conducted every day in the teacher's room before the learning activities. The teaching was performed with solicitation, encouragement, enlightenment, criticism, and feedback to practice. This idea is supported by philosophical words in the form of go' et (idiomatic), which aims to move thoughts, hearts, intentions, and actions together. (Interview, April 24, 26, 28, 2019)

The dimensions of lonto leok teaching that support the effectiveness of the principal's role in optimizing the implementation of CES are presented in table 3 below.

Table 3

The Six-Point of LLCTDA Applied by the Principals

\begin{tabular}{|c|c|l|}
\hline $\begin{array}{c}\text { Teaching Dimensions } \\
\text { of Lonto Leok }\end{array}$ & (Go'et/ idioms) & $\begin{array}{c}\text { The Contents of the Lonto Leok Lesson Given by the } \\
\text { Principals }\end{array}$ \\
\hline $\begin{array}{c}\text { Tatong (encouraging } \\
\text { progress and change) }\end{array}$ & $\begin{array}{c}\text { anggom taung; nipu riwu, } \\
\text { ongko do (unity/togetherness) }\end{array}$ & $\begin{array}{l}\text { Inviting and encouraging all components of the } \\
\text { school to work together to achieve progress, based } \\
\text { on the vision, mission and shared goals }\end{array}$ \\
\hline $\begin{array}{c}\text { Toing (teach how to } \\
\text { solve problems) }\end{array}$ & $\begin{array}{c}\text { lewing ngombek, kebor léwé } \\
\text { (breadth of knowledge) }\end{array}$ & $\begin{array}{l}\text { Inviting and giving flexibility to teachers and } \\
\text { employees to use their competencies to solve old } \\
\text { problems in new ways }\end{array}$ \\
\hline $\begin{array}{c}\text { Toto Nai Bakok } \\
\text { (shows an expression } \\
\text { of partiality) }\end{array}$ & $\begin{array}{c}\text { neho waé nggéreng ati agu } \\
\text { nain (as clear as water, heart, } \\
\text { and feeling) }\end{array}$ & $\begin{array}{l}\text { Giving appreciation for the work of teachers and } \\
\text { employees. Appreciating contributions, fostering } \\
\text { confidence, attention, empathy for all components } \\
\text { of the school }\end{array}$ \\
\hline $\begin{array}{c}\text { Titong (gives guidance } \\
\text { for acting responsibly) }\end{array}$ & $\begin{array}{c}\text { t'oing agu wahéng } \\
\text { (instructions and advice) }\end{array}$ & $\begin{array}{l}\text { Invite, encourage staffs, teachers, and employees to } \\
\text { work professionally to achieve common interests }\end{array}$ \\
\hline $\begin{array}{c}\text { Tatang or Titing } \\
\text { (Reinforcing and } \\
\text { empowering) }\end{array}$ & $\begin{array}{c}\text { kudut kantis ati, cengka lemas, } \\
\text { huru nuk, helu nai (strengthens } \\
\text { the intention to do something } \\
\text { better and successful) }\end{array}$ & $\begin{array}{l}\text { Motivating teacher staffs and employees to work } \\
\text { beyond the planned target }\end{array}$ \\
\hline $\begin{array}{c}\text { Bantang Cama Reje } \\
\text { Leleng (cooperation / } \\
\text { participating) }\end{array}$ & $\begin{array}{c}\text { ipung ca tiwu neka woleng } \\
\text { tombo, (together fighting for } \\
\text { common interests) }\end{array}$ & $\begin{array}{l}\text { Encouragement to work together (schools, parents, } \\
\text { and the community) }\end{array}$ \\
\hline
\end{tabular}

Referring to the six aspects of the lonto leok teaching dimensions presented in table 3; in optimizing the program of character education strengthening in schools, the strategic steps of the principals are as follows:

(a) Designing four types of CESP; (1) self-development, (2) classroom learning, (3) school environment, and (4) community environment. The four programs were carried out through two stages of lonto leok. In the first lonto leok stage, the work team was coordinated to determine the activity, while in the second lonto leok stage, the activities were socialized.

(b) The first and second lonto leok activities were completed at the beginning of the school year. Contrarily, the third and fourth lonto leok stages were carried out every three months in the semester.

The steps of the principal's transformational leadership in coordinating and socializing the types of activities, based on the LLCTDA, are described in table 4. 
Table 4

Types of Programs and Strategic Steps of Principals in Coordinating the Implementation of Activities

\begin{tabular}{|c|c|c|c|c|}
\hline Type of CESP & \multicolumn{4}{|c|}{ Activity Coordination } \\
\hline $\begin{array}{l}\text { 1. Self- } \\
\text { Development }\end{array}$ & $\begin{array}{l}\text { First Lonto Leok } \\
\text { Coordination of } \\
\text { the Work Team }\end{array}$ & $\begin{array}{c}\text { Types of Activities } \\
\text { Undertaken }\end{array}$ & $\begin{array}{l}\text { Second Lonto } \\
\text { Leok } \\
\text { Socialization of } \\
\text { Activities }\end{array}$ & Types of Activities \\
\hline $\begin{array}{l}\text { a) Regular school } \\
\text { activities }\end{array}$ & $\begin{array}{l}\text { The chief } \\
\text { coordinator of } \\
\text { the students' } \\
\text { affairs, } \\
\text { homeroom } \\
\text { teacher, subject } \\
\text { matter teacher }\end{array}$ & $\begin{array}{l}\text { Discuss routine } \\
\text { activities carried } \\
\text { out by students at } \\
\text { school }\end{array}$ & $\begin{array}{l}\text { Homeroom } \\
\text { Teacher and } \\
\text { students }\end{array}$ & $\begin{array}{l}\text { Cleaning classroom and } \\
\text { toilet, distributing the flag } \\
\text { ceremony groups, checking } \\
\text { students' attendance }\end{array}$ \\
\hline $\begin{array}{l}\text { b) Spontaneous } \\
\text { activities }\end{array}$ & $\begin{array}{l}\text { Homeroom } \\
\text { teacher, subject } \\
\text { matter teacher, } \\
\text { teacher guidance } \\
\text { and counselling }\end{array}$ & $\begin{array}{l}\text { Discuss student } \\
\text { behavior that is } \\
\text { prohibited while in } \\
\text { the school } \\
\text { environment }\end{array}$ & $\begin{array}{l}\text { Homeroom } \\
\text { teacher and } \\
\text { students }\end{array}$ & $\begin{array}{l}\text { Disorderly throwing garbage, } \\
\text { producing noise in class, } \\
\text { being violence, being not } \\
\text { polite, stealing, being } \\
\text { disrespectful, saying dirty } \\
\text { words }\end{array}$ \\
\hline c) Exemplary & $\begin{array}{l}\text { Head of the } \\
\text { student affairs } \\
\text { coordinator, } \\
\text { homeroom } \\
\text { teacher, subject } \\
\text { matter teacher, } \\
\text { daily pickets' } \\
\text { students, } \\
\text { employees }\end{array}$ & $\begin{array}{l}\text { building a shared } \\
\text { commitment to set } \\
\text { an example of } \\
\text { ethical behavior in } \\
\text { school }\end{array}$ & $\begin{array}{l}\text { All teachers and } \\
\text { employees }\end{array}$ & Behave well in school \\
\hline Principal's TLB & \multicolumn{4}{|c|}{$\begin{array}{l}\text { Structure development for participatory and professional values practices; through the } \\
\text { cooperation with parents, the community in teaching students. This step is in line with the } \\
\text { LLCTDA, namely "bantang cama reje leleng" (building cooperation), and "titong" (giving } \\
\text { guidance for doing something responsibly) }\end{array}$} \\
\hline \multicolumn{5}{|l|}{ 2. Class Activities } \\
\hline $\begin{array}{l}\text { a) Integrated into } \\
\text { Learning }\end{array}$ & $\begin{array}{l}\text { Principal, head of } \\
\text { the curriculum } \\
\text { affairs } \\
\text { coordinator }\end{array}$ & $\begin{array}{l}\text { Controlling the } \\
\text { completeness of } \\
\text { learning devices } \\
\text { prepared by the } \\
\text { teachers }\end{array}$ & $\begin{array}{l}\text { head of the } \\
\text { curriculum } \\
\text { affairs } \\
\text { coordinator }\end{array}$ & $\begin{array}{l}\text { Arranging character syllabus, } \\
\text { character implementation } \\
\text { plan, character teaching } \\
\text { material, assessment format }\end{array}$ \\
\hline $\begin{array}{l}\text { b) Class } \\
\text { Management }\end{array}$ & $\begin{array}{l}\text { Head of the } \\
\text { curriculum affairs } \\
\text { coordinator, head } \\
\text { of the student } \\
\text { affairs } \\
\text { coordinator, } \\
\text { homeroom } \\
\text { teacher, subject } \\
\text { matter teacher, }\end{array}$ & $\begin{array}{l}\text { Discussing the } \\
\text { standards of } \\
\text { students' behavior } \\
\text { in class, and put it } \\
\text { in student } \\
\text { discipline books, } \\
\text { along with the } \\
\text { scores on violations } \\
\text { and points of }\end{array}$ & $\begin{array}{l}\text { Homeroom } \\
\text { teacher and } \\
\text { students }\end{array}$ & $\begin{array}{l}\text { Listening to teacher teaching, } \\
\text { respecting friends' thoughts, } \\
\text { ethical ways of asking } \\
\text { questions, comfortable } \\
\text { classroom environment, peer } \\
\text { tutoring, punishment when } \\
\text { there are violation and } \\
\text { reward for disciplined } \\
\text { behavior }\end{array}$ \\
\hline
\end{tabular}




\begin{tabular}{|c|c|c|c|c|}
\hline & $\begin{array}{l}\text { student discipline } \\
\text { coordinator }\end{array}$ & violation sanctions & & \\
\hline $\begin{array}{l}\text { c) Learning } \\
\text { Stages }\end{array}$ & $\begin{array}{l}\text { Head of the } \\
\text { curriculum affairs } \\
\text { coordinator with } \\
\text { homeroom } \\
\text { teacher carry out } \\
\text { a consultation for } \\
\text { the subject } \\
\text { teacher }\end{array}$ & $\begin{array}{l}\text { Synchronizing the } \\
\text { steps of learning }\end{array}$ & $\begin{array}{l}\text { Homeroom } \\
\text { teacher and } \\
\text { students }\end{array}$ & $\begin{array}{l}\text { An example of the lonto leok } \\
\text { based character learning } \\
\text { stage is presented in } \\
\text { Appendix } 1\end{array}$ \\
\hline Principal's TLB & \multicolumn{4}{|c|}{$\begin{array}{l}\text { Build a shared vision, work professionally, give stimulation to the knowledge of } \\
\text { subordinates, so that they can do more than what is needed for the progress of the school, } \\
\text { which is reinforced by the LLCTDA, "tatong" (encouraging progress), "toing" (teaching how } \\
\text { to solve problems), and "titong" (giving guidance on doing things responsibly) }\end{array}$} \\
\hline \multicolumn{5}{|l|}{$\begin{array}{c}\text { 3. School } \\
\text { Environment }\end{array}$} \\
\hline $\begin{array}{l}\text { a) Extra- } \\
\text { curricular } \\
\text { (inter-class } \\
\text { sports, vocal } \\
\text { group } \\
\text { competitions, } \\
\text { speech } \\
\text { competitions, } \\
\text { regional } \\
\text { cultural arts } \\
\text { performance } \\
\text { s) }\end{array}$ & $\begin{array}{l}\text { Principal, head of } \\
\text { the curriculum } \\
\text { affairs } \\
\text { coordinator, head } \\
\text { of the student } \\
\text { affairs } \\
\text { coordinator, head } \\
\text { of a coordinator } \\
\text { for community } \\
\text { relations affairs, } \\
\text { sports teachers, } \\
\text { extra-curricular } \\
\text { teachers }\end{array}$ & $\begin{array}{l}\text { Discuss joint } \\
\text { activities by the } \\
\text { program that has } \\
\text { been compiled }\end{array}$ & $\begin{array}{l}\text { Each coach } \\
\text { team }\end{array}$ & $\begin{array}{l}\text { Football matches, inter-class } \\
\text { volleyball and between } \\
\text { schools; English, Indonesian } \\
\text { and regional language } \\
\text { speech contests; vocal group } \\
\text { competition between classes } \\
\text { with folk songs; debate } \\
\text { competition with the theme } \\
\text { of nationalism, cultural } \\
\text { diversity, tourism; cultural } \\
\text { arts performances both at } \\
\text { school, and in collaboration } \\
\text { with the tourism } \\
\text { department, and PT Angkasa } \\
\text { Pura (Komodo Airport) }\end{array}$ \\
\hline $\begin{array}{l}\text { b) Local content } \\
\text { learning }\end{array}$ & $\begin{array}{l}\text { Head of the } \\
\text { curriculum affairs } \\
\text { coordinator with } \\
\text { teachers of local } \\
\text { wisdom subjects }\end{array}$ & $\begin{array}{l}\text { Discuss together } \\
\text { the preparation of } \\
\text { learning tools and } \\
\text { local content } \\
\text { material related to } \\
\text { the Manggarai } \\
\text { culture }\end{array}$ & $\begin{array}{l}\text { Local content } \\
\text { subject teachers } \\
\text { and students }\end{array}$ & $\begin{array}{l}\text { Syllabus, learning } \\
\text { implementation plans, } \\
\text { teaching materials, and } \\
\text { learning models; field studies } \\
\text { (visits to cultural sites) }\end{array}$ \\
\hline Principal's TLB & \multicolumn{4}{|c|}{$\begin{array}{l}\text { Intellectual stimulation, development of structures for participation, initiative, creativity, } \\
\text { and innovation in teaching students and learning from the community. This step is } \\
\text { supported by the application of the LLCTDA, "toing" (teaching how to overcome problems), } \\
\text { and "bantang cama reje leleng" (cooperation in teaching students) }\end{array}$} \\
\hline \multicolumn{5}{|l|}{$\begin{array}{l}\text { 4. Community } \\
\text { Environment }\end{array}$} \\
\hline $\begin{array}{l}\text { a) Lutur Lewe } \\
\text { (Shared } \\
\text { House) }\end{array}$ & $\begin{array}{l}\text { Teaching and } \\
\text { counselling } \\
\text { teacher team, } \\
\text { head of the } \\
\text { student affairs }\end{array}$ & $\begin{array}{l}\text { Discuss family } \\
\text { visits, so that } \\
\text { parents can take } \\
\text { preventive and } \\
\text { curative actions in }\end{array}$ & $\begin{array}{l}\text { Teaching and } \\
\text { counselling } \\
\text { teacher team } \\
\text { with students } \\
\text { and parents }\end{array}$ & $\begin{array}{l}\text { Schedule home visits and } \\
\text { coordinate with parents }\end{array}$ \\
\hline
\end{tabular}




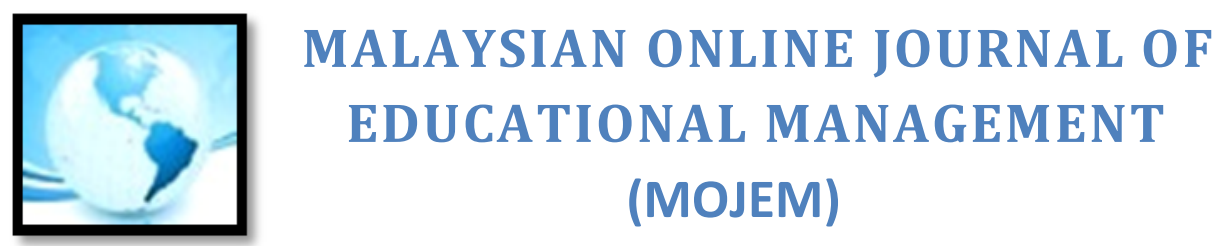

\begin{tabular}{|c|c|c|c|c|}
\hline & $\begin{array}{l}\text { coordinator, } \\
\text { teacher guardian } \\
\text { of the student }\end{array}$ & handling students & & \\
\hline $\begin{array}{l}\text { b) House of } \\
\text { Culture }\end{array}$ & $\begin{array}{l}\text { Head of a } \\
\text { coordinator for } \\
\text { community } \\
\text { relations affairs, } \\
\text { and coaches of } \\
\text { cultural groups }\end{array}$ & $\begin{array}{l}\text { Discuss the steps to } \\
\text { establish } \\
\text { cooperation with } \\
\text { cultural leaders } \\
\text { (Tua Golo) and } \\
\text { schedule visits to } \\
\text { traditional houses } \\
\text { (mbaru gedang) }\end{array}$ & $\begin{array}{l}\text { Team to guide } \\
\text { groups of } \\
\text { cultural lovers, } \\
\text { students, and } \\
\text { cultural leaders }\end{array}$ & Live in culture \\
\hline $\begin{array}{c}\text { The Principal's } \\
\text { TLB }\end{array}$ & \multicolumn{4}{|c|}{$\begin{array}{l}\text { Structure development for participatory and professional values practices; through } \\
\text { cooperation with parents, the community in teaching students. This step is in line with the } \\
\text { LLCTDA, namely "bantang cama reje leleng" (building cooperation), and "titong" (giving } \\
\text { guidance for doing something responsibly) }\end{array}$} \\
\hline
\end{tabular}

\section{b. Evaluation phase}

The principal's strategy in evaluating CESP was carried out through three stages of lonto leok. The stages of evaluation activities are explained by the principals as follows.

First, internal evaluation, between parties responsible for implementing the program (class caregivers, guidance and counselling teacher team, and student discipline teacher team) with students (third lonto leok stage) (Interview, May 08, 10, 14, 2019)

At this stage, the homeroom teacher informed the results of the students' behavioural assessment, which was obtained from the teacher team, and the guidance and counselling teacher team for all students in the class. After that, the homeroom teacher, along with guidance and counselling teacher, provided ethical guidance to students in the classroom.

Second, the homeroom teacher was asked to report the results of the internal evaluation of the work team group (Interview, May 08, 10, 14, 2019)

Then, the work team assessed the advantages and disadvantages of the program that has been implemented and recommended new programs that are more innovative during the evaluation activities with the principal, supervisors, and parents, students.

Third, the work team group reported the results of the evaluation to principals, supervisors, and parents, and recommends program innovations. (Interview, May 08, 10, 14, 2019)

Furthermore, the principal, school supervisor, and parents provided feedback and input for further program optimization. A summary of the final phases of program evaluation is illustrated in figure 2 below. 


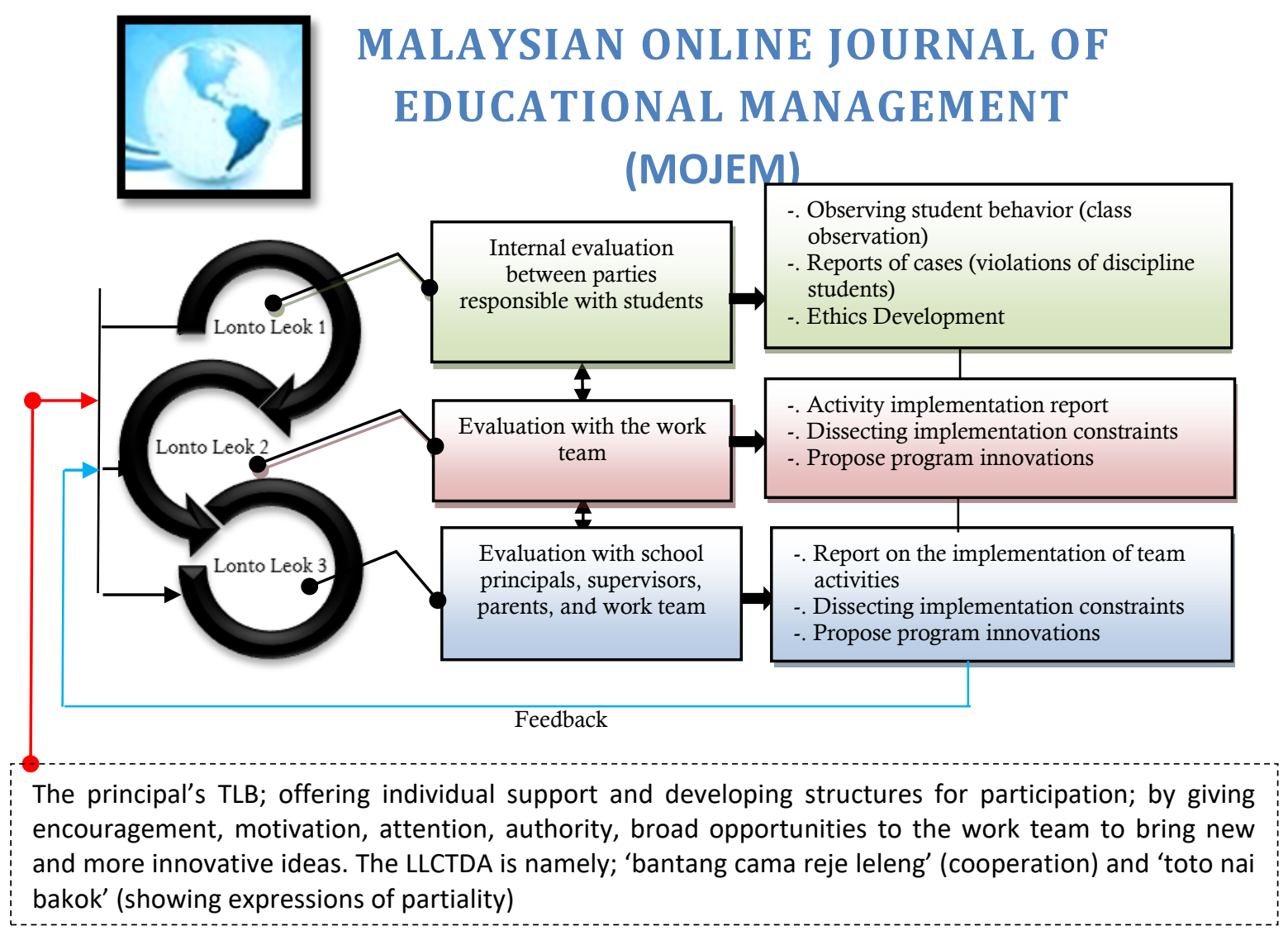

Figure 2. Stages of the Lonto Leok Program Evaluation

\section{DISCUSSION}

\section{The Lonto Leok Values as the Main Values of Character in The School}

In regard to the revitalization of national education policies by the Indonesian government, in optimizing programs to CES in schools, it becomes an essential and urgent demand to use LCMV as one of the central values of character standards. The LCMV implementation is considered extremely relevant to the school's vision, mission, goals, and uniqueness. Besides, the LCMV has animated the life behavior of local students.

At this level, three junior high schools in Manggarai Regency, West Flores - East Indonesia, have adopted the LLCMV of the Manggarai community as the central character values in schools. The LLCMV that are used as standard values of the main characters in school is explained as follows. First, democracy, which positions the school environment as a place for the process of humanization (respecting the potential of students), personalization (student uniqueness), and socialization (self-actualization of students). Democracy class is used as a place for students to sharpen their mindset through discussion space, study, and criticize new ideas and build self-confidence (Kocoska, 2009).

In schools, the value of democracy is applied through respect for others, humility, brotherhood, harmony, peace, justice, and respect for diversity. In learning developed, it will be through; involvement of students in planning classroom activities, problem-solving in class, and decision making (Koesoema, 2017; MoE, 2017). Second, the value of unity is practiced through cooperation in solving problems in family and society. In school, it is instilled through participation, kinship, solidarity, and integrity. Unity values are the main value in building the integrity of the life of the nation and state.

Third, the value of peace is implemented through actions to avoid conflict, so that a sense of security, peace, and peace can be assured. It is expected that in lonto leok's activities, students will not get angry quickly because of their different opinions, do not force their ideas, do not dominate the conversation, and know the ethics of 


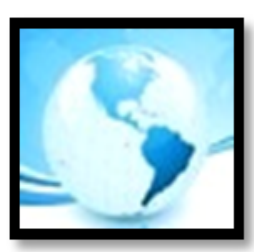

\section{MALAYSIAN ONLINE JOURNAL OF EDUCATIONAL MANAGEMENT (MOJEM)}

speaking. In schools, the value of peace is applied in the form of; friendly, unselfish, respecting the dignity of others. The peace values are included in the school curriculum and communication skills, in respecting different opinions, working together to solve problems, and thinking critically. Fourth, the value of love, which is inspired by Christian spirituality (relationship with the highest being/Mori Kraeng). In school, the value of love is developed through attitude, religion, solider, cultured, and ecological spirit. The personal integrity of love is reflected in three relational dimensions, which include interpersonal relations with God as homo religious, social connections with others as social beings, and personal relationships with the natural environment. In learning, through religious values-based learning models, school environment conditioning, habituation, and loving attitude (Lickona, 2012).

Fifth, the value of justice in lonto leok is interpreted through the distribution of agricultural land (lingko) and fair rules of life. At schools, this value is applied through fair treatment and respect for the rights of others. According to Power and Higgins-D'Alessandro (2008), if you want to instil the character of the value of justice, then you; (a) need to avoid various forms of injustice, fraud, and lies, discrimination in religion, ethnicity, social class; (b) need flexible school rules, and (c) a sporty school atmosphere that respects diversity and participatory democracy. Sixth, the value of honesty, in the activity of lonto leok is embodied through honest words, so that every problem can be solved wisely. At school, it is necessary to form honest character in students through the behavior of teachers who are honest and disciplined at every opportunity (Yaumi, 2014). Seventh, the value of hard work, in the activity of lonto leok, is grown in the spirit of building a better life through hard work. In school, the value of hard work is inculcated in the form of willingness to sacrifice, discipline, struggle, and responsibility. The value of this hard work is translated into learning behavior and quality task completion (Koesoema, 2017). Eighth, the aspect of hospitality is shown in creating intimacy with others. Therefore, the habit of greeting, approaching, being together, and communicating with others needs to be highlighted. In schools, the value of hospitality is applied through family spirit, a friendship between teachers and teachers, teachers with students, teachers with parents and communities, and among fellow students

\section{Principals Transformational Leadership Based on Lonto Leok's Culture Teaching Approach}

Overcoming the sub-optimal implementation of CESP in Indonesia has become an essential and urgent demand to improve the principal's leadership role. In the context of our study, the debate over cross-cultural management is reaffirmed, relating to specific management practices suiting a variety of cultural backgrounds. That is debated in terms of how well the application of management practices can be transferred between cultures (Hofstede, 1993). At this level, culture and leadership are explained in terms of two sides of the same coin. Culture and leadership cannot be understood separately: on the one hand, culture influences how organizations will interpret leadership; on the other hand, the leader's competence is the ability to get to know and work with culture. In this case, the capability to recognize the limitations of one's own culture and to describe the culture adaptive is the fundamental nature and challenge of leadership. Leithwood and Jantzi (2006) explain that a new leader replaces an existing organization if he realizes that the culture that already exists in that organization will determine and influence his leadership style. Besides, leadership in organizations is guided by pragmatic visions relating to types of culture advance performance.

In the context of this research, especially in optimizing the implementation of CESP applied the TLB approach developed by Podsakoff et al. (1990), and Leithwood and Jantzi (1999), such as; articulating the vision; provide intellectual stimulation; offering individual support (responsive to individual needs through giving humane treatment), offering intellectual stimulation (thinking of old problems in new ways); describing professional practices and values; showing high-performance expectations, and developing structures to encourage participation in school decisions. The effectiveness of the TLB of the school principal is supported through a dimensional approach of traditional leadership in the values of individualism-collectivism developed by Hofstede (2001). This dimension of individuality is used by principals in the form of rewarding individuals, and teamwork solidarity. 


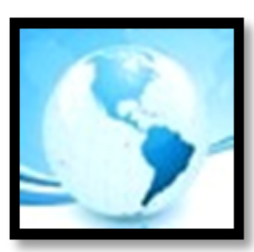

\section{MALAYSIAN ONLINE JOURNAL OF EDUCATIONAL MANAGEMENT (MOJEM)}

In the light of the new research, the principal of the junior high schools, West Manggarai, West Flores - Indonesia, has implemented TLB based on the teaching dimension of the lonto leok of the Manggarai people. The steps of the principals in the planning stage, are; (1) involving various parties to explore and determine the lonto leok values as the central values of school characteristics; (2) as agents of change in revising the formulation of the vision, mission, and objectives of the CESP; (3) collaborating in teams to develop CESP (Leithwood \& Jantzi, 2006). Traditional leadership dimensions, namely individualism-collectivism was developed by Hofstede (2001) to support the steps of the principal, in the form of rewarding individuals, and strengthened teamwork solidarity through the LLCTDA (Hofstede, 2001; Sutam, 2014) was implemented. The implemented LLCTDA are "tatong", "toing", and "bantang cama reje leleng", that represent the invitation and encouragement of the principal to all components of the school to work together in finding innovations, develop a shared vision to achieve school progress.

Through a shared vision, intellectual stimulation, and the development of structures for participation, the principals designed collaborative planning by building collegial relationships that unite knowledge sharing, new ideas, and the achievement of mutual consensus. Besides, dividing clear goals and expectations can be achieved through the vision, mission, goals, and joint work programs that are put together through mutual agreement on goals, collaboration, and shared consensus (Groves \& LaRocca, 2011).

In optimizing the CESP, the principal's strategic steps are explained as follows. First, self-development activities are carried out by targeting high-performance expectations and driven by intellectual stimulation. Practical steps were taken by principals, namely, providing inspirational motivation and giving trust to teachers, employees to develop initiative, creativity, and innovation so that they find new ways of overcoming old habits, thus exceeding planned results (Leithwood \& Jantzi, 2006). The LLCTDA that supports the principal's steps is "tatang or titing" and "toing", namely empowering teacher and employee competencies, being open to accepting new ideas, and new practices to optimize CESP (Sutam, 2014).

Second, class activities are carried out using; build a shared vision and carry out tasks professionally and responsibly, in designing character learning (designing tools, models and assessment of learning), and empowering and stimulating the knowledge of teachers to become competent and professional transformational instructors, so that instructor satisfies and trust (Valentine \& Prater, 2011). To maximize the role of the principal, the LLCTDA applied is "toing" (teaching how to overcome problems), and "titong" (giving guidance for doing something responsibly). Both of these approaches are implemented in; (1) providing technical guidance on character learning to teachers, (2) providing space for freedom, foster optimism, work creativity so that it works without being ruled, creative and innovated, (3) motivating teachers to translate the theory of learning, work professionally to achieve goals, (4) encouraging teachers to accompany students with heart and love, and (5) developing concrete and effective moral behavior both in school and society (Sutam, 2014).

Third, the implementation of the school environment. Positive school culture, according to Macneil, Prater, and Busch (2009), and Bosworth, Ford, and Hernandez (2011), are described by 1) high student motivation and achievement, 2) collaboration between schools, government, and schools. The school principals' transformative step is to empower staff and to develop structures for participation in creating a positive school culture. The stage of the principals aims to provide opportunities for the teacher to be innovative in guiding students in the school environment. This step is supported by the application of the LLCTDA, in the form of; "toing" (teaching how to overcome problems), and "bantang cama reje leleng" (cooperation in teaching students).

Fourth, community-based. Community-based education is an educational model that engages the community in the administration and management of education (Tilaar, 2005). The contribution of the principals in building a network of community environmental cooperation is carried out using; (1) interaction and dialogue, (2) empowering students with cultural knowledge through the lutur lewe program, (3) giving authority to the work team, to establish communication with old golo (traditional leaders), (4) discussing visits to traditional houses (mbaru gendang) and living with cultural communities (Musana, 2011). The LLCTDA which strengthens this role of 


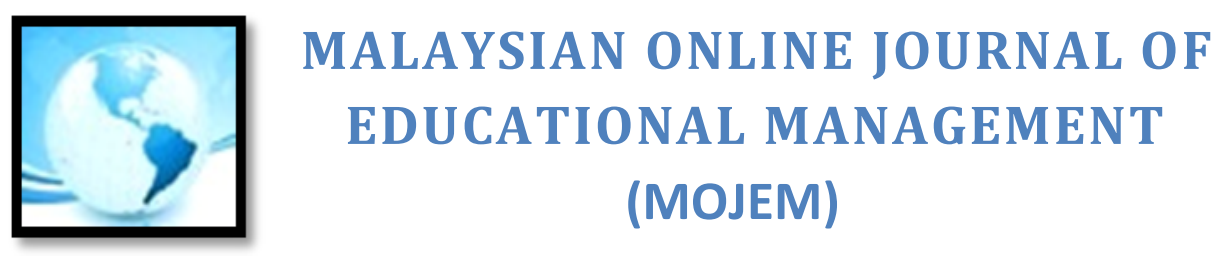

the principals, through "bantang cama reje leleng" (cooperation). Through collaboration, the community supports CESP, by providing opportunities for students to learn from the cultural environment; supporting schools to optimize CESP; becoming partners in evaluating school programs and participating in school policymaking.

In evaluating CESP, the steps of the principals are; offering individual support and developing structures for participation; by giving encouragement, motivation, attention, and support, appreciation, and opportunities to the work team to create new and more innovative ideas. The LLCTDA that supports the role of the principals, namely; 'bantang cama reje leleng' (building joint work) by developing the skills of subordinates to use their own decisions responsibly; and 'toto nai bakok' (showing expressions of partiality), through honest and sincere recognition to give appreciation to the work of teachers, employees. They appreciate contributions, foster confidence, attention, trustworthiness, empathy, and attention to the needs of teachers, employees, and students at school. The steps of the principals are one of the characteristics of TLB (Piccolo \& Jason, 2006).

\section{CONCLUSION AND IMPLICATIONS}

In light of the latest research, the values of lonto leok as a cultural heritage of the Manggarai community, are instrumental in shaping the character of students in school. This success is supported by the principal's transformational leadership role through the LLCTDA. The findings in this research can be used as a recommendation to the Indonesian National Directorate of Education and Culture so that every school in Indonesia is given a space to explore and use local wisdom values as a core standard of character values, as well as to encourage all principals to apply transformational leadership approaches based on the dimensions of teaching local culture.

Based on the results of the study, this study contributed positively to the optimization of the implementation of CESP. During this time, the implementation of CES has not been carried out optimally in schools. Each school has not yet found a definite character education model, which results in an unclear application. To overcome the existing problems, the school principal, supported by teachers, employees, parents, school committees, school supervisors, and cultural leaders, takes the policy in order to use the moral values of local culture as the standard values of the main characters of the school. This policy is based on efforts to optimize national character values that are still universal, conceptual, and anonymous. This research provides an original contribution to the development of local culture-based leadership concepts. Therefore, the development of the idea of leadership in the future can unite TLB with local cultural approach patterns, as one of the innovative leadership models. On this basis, an effective leader needs to learn and apply local cultural approach patterns, whether he is from outside the local cultural environment, or from that cultural environment. This is based on the work performance of people who conditioned by behavioural patterns influenced by the culture they live in.

\section{REFERENCES}

Ardiawan, I. K. N. (2018). Ethno pedagogy And Local Genius: An ethnographic study. SHS Web of Conferences, 42 , 00065. https://doi.org/10.1051/shsconf/20184200065

Bass, B. M. (1997). Does the transactional-transformational leadership paradigm transcend organizational and national boundaries? American Psychologist, 52(2), 130-139. https://doi.org/10.1037/0003-066X.52.2.130

Bosworth, K., Ford, L., \& Hernandez, D. (2011). School climate factors contributing to student and faculty perceptions of safety in select Arizona schools. Journal of School Health, 81(4), 194-201.

Character Education Partnership. (2002). Eleven principles of effective character education. Retrieved from http://www.character.org/principles/.

Creswell, J. W. (2012). Educational research: Planning, conducting, and evaluating quantitative and qualitative research (4th Ed.). Boston, USA: Pearson. 


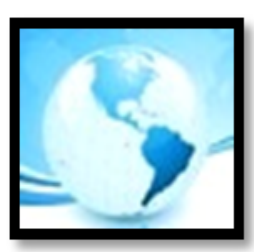

\section{MALAYSIAN ONLINE JOURNAL OF EDUCATIONAL MANAGEMENT (MOJEM)}

Hartog, N. D., Hangees, P., Dorfman, W. P., \& Ruiz-Quintanilla, A. S. (1999). Culture-specific and cross-culturally generalizable implicit leadership theories: Are attributes of charismatic transformational leadership universally endorsed? Leadership Quarterly, 10(2), 219-256.

Erb, M. (2005). Shaping a 'New Manggarai': Struggles over culture and tradition in an Eastern Indonesian regency. Asia Pacific Viewpoint, 46(3), 323-334.

Government Regulation (PP). (2017) No. 87 of 2017 Concerning Strengthening Character Education. Indonesia: Office of Assistant to Deputy Cabinet Secretary.

Groves, K. S., \& LaRocca, M. A. (2011). An empirical study of leader ethical values, transformational and transactional leadership, and follower attitudes toward corporate social responsibility. Journal of Business Ethics, 103(4), 511-528.

Hofstede, G. (1993). Cultural constraints in management theories. Academy of Management Executive, 7, 81-94. http://dx.doi.org/10.5465/ame.1993.9409142061.

Hofstede, G. (1984). Cultures consequences: International differences in work-related values. Beverly Hills: Sage Publications.

Hofstede, G. (2001). Culture's consequences: Comparing values, behaviors, institutions, and organizations across nations. Thousand Oaks, CA: Sage Publications, Inc.

House, R. J., Hanges, P. J., Ruiz-Quintanilla, S. A., Dorfman, P. W., Javidan, M., Dickson, M., Gupta, V. (1999). Cultural influences on leadership and organizations: ProjectGLOBE. In W. H. Mobley, M. J. Gessner, \& V. Arnold (Eds.), Advances in GlobalLeadership (pp. 171-233). Stamford, CT: JAI Press.

Irawanto, D. W., Ramsey, P. L., \& Ryan, J. C. (2011). Challenge of leading in Javanese culture. Asian Ethnicity, 12(2), 125-139.

Kleden, I. (1987). Scientific attitudes and cultural criticism. Jakarta: LP3ES.

Kocoska, J. (2009). The student's position in the democratic classroom, in the World Conference on Educational Sciences. Procedia Social and Behavioral Sciences, 1, 2429-2431.

Koesoema, D. A. (2017). Character education strategy, mental revolution in educational institutions. Yogyakarta: Kanisius.

Ladson-Billings, G. (1992). Reading between the lines and beyond the Pages. A culturally relevant approach to literacy teaching. Theory Into Practice, 31(4), 312-320.

Leithwood, K., \& Jantzi, D. (1999). Transformational school leadership effects: A replication. School effectiveness, and school improvement. An International Journal of Research, Policy, and Practice, 10(4), 451-479.

Leithwood, K., \& Jantzi, D. (2006). Transformational school leadership for large-scale reform: Effects on students, teachers, and their classroom practices. School Effectiveness and School Improvement, 17(2), 201-227.

Lickona, T. (2012). Education for character: Educating for character shaping. Jakarta: PT Bumi Aksara.

Macneil, A. J., Prater, D. L., \& Busch, S. (2009). The effect of school culture and climate on student achievement. International Journal of Leadership in Education, 12(1), 73-84.

Miles, M. B., Huberman, A. M., \& Saldaña, J. (2014). Qualitative data analysis: A methods sourcebook (3rd Ed.). Arizona State University: SAGE Publications, Inc.

Musana, A. (2011). Local wisdom rationality and actuality as a character education base. Journal of Education and Culture, 17(6), 588-598.

Nieto, S. (2008). Culture and education. Yearbook of the National Society for the Study of Education, 107(1), 127142.

Nggoro, A. M. (2013). Manggarai culture at a glance. Ende: Nusa Indah.

Obanya, P. (2005). Culture in education and education in culture. Paper presented at Fifth Conference Of African Ministers Of Culture, 10-14 December 2005 Nairobi, Kenya. Retrieved from https://www.africa-union.org.

Piccolo, R. F., \& Jason, A. C. (2006). Transformational leadership and job behaviors: The mediating role of core job characteristics. Academy of Management Journal, 49(2), 327-340.

Podsakoff, P. M., MacKenzie, B. S., Moorman, R. H., \& Fetter, R. (1990). Transformational leader behaviors and their effects on followers' trust in leader, satisfaction, and organizational citizenship behaviors. The Leadership Quarterly, 1(2), 107-142. https://doi.org/10.1016/1048-9843(90)90009-7. 


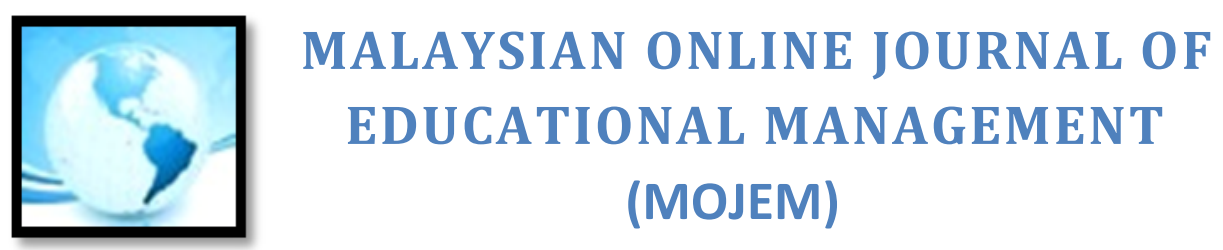

Power, F. C., \& Higgins-D'Alessandro, A. (2008). The just community approach to moral education and the moral atmosphere of the school. In L. P. Nucci \& D. Narvaez (Eds.). Handbook of Moral and Character Education (pp.230-247). New York: Routledge, Taylor \& Francis Group.

Spreitzer, G. M., Hopkins, K. P., \& Xin, K. (2005). Traditionality matters: An examination of the effectiveness of transformational leadership in the United States and Taiwan. Journal of Organizational Behavior, 26(3), 205-227. https://doi.org/10.1002/job.315.

Surya, I. B. K., Thoyib, A., Fatchan, A., \& Rahayu, M. (2014). Tri Hita Karana culture effect on company performance, leadership and organizational commitment (Studies a Regional Water Company in Bali Province). International Journal of Business and Management Invention, 3(6), 13-22.

Sutam, I. (2014). Education in the perspective of culture Manggarai. Ruteng: STKIP St. Paulus Ruteng.

Tapung, M., Maryani, E., Lon, Y., Payong, M., \& Supriatna, N. (2018). Developing the value of "lonto leok" in Manggarai culture to empower the skills of social problem-solving in social-sciences learning of junior-high school. In Proceedings of the Annual Conference on Social Sciences and Humanities (ANCOSH 2018). SCITEPRESS - Science and Technology Publications.

The Ministry of Education. (2017). Strengthening character education training modules for school principals. Jakarta: Secretariat Team.

Tilaar, H. A. R. (2005). National education manifesto review of postmodernism and cultural studies. Jakarta: Kompas.

UNESCO. (2012). Education of sustainable development. Sourcebook. France: United Nations Educational, Scientific, and Cultural Organization.

Valentine, J., \& Prater, M. (2011). Instructional, transformational, and managerial leadership and student achievement: High school principals make a difference. NASSP Bulletin, 95(1), 5-30.

Verheijen. (1967). Dictionary of Manggarai II: Indonesia-Manggarai. Ende: Percetakan Arnoldus.

Wibowo, A. (2015). Character education management in schools. Yogyakarta: Pustaka Pelajar.

Yammarino, F. J., Dubinsky, A. J., \& Spangler, W. D. (1998). Transformational and contingent reward leadership: Individual, dyad, and group level of analysis. The Leadership Quarterly, 9 (1), 27-54.

Yaumi, M. (2014). Character Education: Platforms, pillars \& implementation. Jakarta: Predana Media Group.

Yin, R. K. (2017). Case study research and applications: Design and methods. London: Sage Publications.

Yunus, R. (2014). The values of local wisdom (local genius) as the reinforcement of national character: Empirical studies on Huyula. Yogyakarta: Deepublish. 